ISSN: 2581-8341

Volume 04 Issue 04 April 2021

DOI: 10.47191/ijcsrr/V4-i4-02, Impact Factor: 5.825

IJCSRR@ 2021

www.ijcsrr.org

\title{
Home Range and Distance Covered of Chukar Partridge Alectoris Chukar at Mandal Valley, Garhwal Himalaya, India
}

\author{
Manish Kukreti $^{1}$, S.P. Uniyal ${ }^{2}$ \\ ${ }^{1,2}$ Department of Zoology Govt. P.G. College Gopeshwar, Chamoli
}

\begin{abstract}
Present paper reports Home range and distance covered of Chukar partridge at mandal valley, Garhwal Himalaya from November 2018 to October 2019. During the study period, average home range (altitude M) of Chukar was $1756.75 \pm 7.75$ and average distance covered from water source $69.52 \pm 6.76(\mathrm{M})$, maximum range observed in month of June (1812 \pm 8.0$)$ while minimum range observed in November month (1708 \pm 5.0$)$ respectively. Maximum distance covered observed in August month (99.04 \pm 11.42$)$ and minimum distance covered recorded in month of May (41.10 \pm 4.83$)$. Seasonal variation was also observed, Maximum range in Summer season $(1803 \pm 10.33)$ and minimum observed in winter season $(1713.33 \pm 8.0)$, seasonal variation also observed in monsoon and post monsoon season $(84.85 \pm 8.77)$ while minimum value was observed in summer season $(47.77 \pm 6.44)$ respectively.
\end{abstract}

KEY WORDS: Home range, distance cover, Chukar, Garhwal Himalaya

\section{INTRODUCTION}

Knowledge on the home range and distance cover of Chukar partridge is vital to identify the appropriate scale at which to explore ecological relationship. The home range and distance cover is the area in which an individual's live and moves in a defined time period and is related to the concept of species territories that is an actively defended. Chukar partridge Alectoris chukar (Gary) is a bird of open semi arid wasteland near crop fields of the hill villages (Ali, 1983, Hume and Marshall, 1879, Chirstensen, 1996). Information on home range and distance covered of chukar is completely lacking especially in the Indian context. Based on longterm studies on home range and distance covered in different altitude were described in this paper.

\section{STUDY SITE AND METHODS}

Long term study for one year (November 2018 to October 2019) was conducted at mandal valley; district Chamoli (30 $24^{\prime} \mathrm{N}$ and $\left.79^{0} 19^{\prime} \mathrm{E}, 1850 \mathrm{M}\right)$. The study site was spread over $4.5 \mathrm{~km}^{2}$ area on the east facing slopes. In every month, camping was made for 10 15 days in the study area. Few vantage points commanding view of all habitats was selected at different altitude to monitor the bird. For down (30minutes before sunrise) to dusk (till setting of dark), Chukar were monitored and data collected on home range, range of attitude and approximate distance covered by partridges from a permanent water source used every day for drinking water was measured. Area was calculated from toposheet map. The data was analyzed by standared statistical methods, viz.' $t$ ' test and ANOVA, wherever required (Fisher, 1963, Snedecor, 1956).

\section{RESULT}

Monthly data on Home range (altitude) and distance covered from permanent water source (used every day for drinking water) by Chukar partridge every day/ month reveal seasonal variation in home range. Monthly data shows that highest range of altitude 1812 \pm 8.0 M. was covered June and minimum 1708 $\pm 5.0 \mathrm{M}$ in January (Table 1).Average distance covered by Chukar ranged from 99.04 \pm 11.42 (Maximum in August) to 41.10 \pm 4.83 (minimum in June) respectively. Seasonal variations was also recorded in range of altitude and distance covered (Table 2). Highest altitude covered by Chukar was $1803 \pm 10.33$ in breeding season (May-June) and minimum 1713.33 \pm 8.0 in winter season (December-January).Maximum distance cover $84.85 \pm 8.77 \mathrm{~m}$. was observed in monsoon and post monsoon season (August, September and October) and minimum 47.77 \pm 6.44 in breeding season (May-June) respectively.

\section{DISCUSSION}

At the intensive study site Mandal valley, Garhwal Himalaya, the altitude and average distance covered from a perennial stream (used daily from drinking water) every day; suggest seasonal variation in home range of Chukar partridge. During monsoon and 


\section{International Journal of Current Science Research and Review}

ISSN: 2581-8341

Volume 04 Issue 04 April 2021

DOI: 10.47191/ijcsrr/V4-i4-02, Impact Factor: 5.825

IJCSRR@ 2021

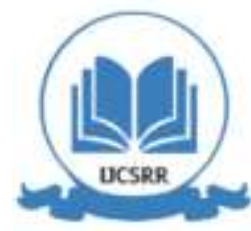

www.ijcsrr.org

post monsoon season, chukars were observed covering high range of altitude and distance, whereas birds found restricted to low altitude during winter (September to February) and smaller area in spring and summer (March to June). Dispersal of Chukars in large area during monsoon period is understandable, because during this phase of life cycle, growing juveniles and sub-adults need more food as observed in Gary partridge Perdix perdix (Smith et.al 1980). Therefore, birds cover large area in search of insect, seeds, leaves etc. In spring and summer seasons (breeding period), birds restrict themselves in narrow range of habitat. During this time, two factors could be restricting home range of Chukar partridge. First reason is that the water source is very close to crop fields, which were used both for feeding and for breeding purposes, second reason is involvement of birds in breeding activates. Therefore, lacking of enough of time compels birds to restrict their habitat range. Dispersal of home range has many advantage (Middleton, 1936, Southwood and Cross, 1969, Weigand, 1980). Large habitat reduce, competition, provides more food and natural resources, give an opportunities for inhabiting in new habitats.

\section{CONCLUSION}

Based on above discussion it can be concluded that wide range of altitude and distance covered is one of the reasons for it common occurrence in spite of hunting and habitat loss. The scrub habitats on steep semi arid slopes which are on large part of the hills of Uttrakhand, could be used for management of Chukar partridge. Especially shrubs like Rhus, Rubus, Berberis, Rosa provide protection cover and food for partridge. These Perennial shrubs along with long gresses would certainly helpful in conservation of partridge diversity.

\section{ACKNOWLEDGEMENT}

Thanks to principal, Government P.G. College Gopeshwar to permit me lab facility during study period, is great fully acknowledged. We have thankful to local people for providing secondary information on occurrence of Chukar Partridge in the study area.

\section{REFERENCES}

1. Ali, S. \& Ripley, S. D.(1983). Handbook of Bird of India and Pakistan. Compact edition, Oxford University Press, New Delhi.

2. Christensen, G.C. 1996. Chukar: Alectoris chukar. The Birds of North America. Philedelphia: The Academy of Natural Sciences of Philedelphia. Ed. Poole, F. G. Pp. 1-20.

3. Fisher, R.A. 1963. Statistical method for research works. Oliver Boyd, London.

4. Hume, A. O. \& Marshall, C. H. T. (1879). The Game Birds of India, Pakistan, Bangladesh, Burma \& Sri Lanka. Calcutta $1: 169-176$.

5. Middleton, A.D. 1936. Factors controlling the Population of the Partridge (Perdix perdix) in Great Britain. Proc. Zool. Soc. London, 106: 795-815.

6. Smith, L.M., Hupp, J.W. and Ratti, J.T. 1980. Reducing abandonment of nest-trapped grey partridge with methoxyflurane. J. Wildlife management, 44: 690-691.

7. Snedecor, G.W. 1956. Statistical methods applied to experiments in agricultural and biology. $5^{\text {th }}$ ed. Ames, Low state collage Press.

8. Southwood, T.R.E., and Cross, D.J. 1969. The ecology of partridge. III. Breeding success and the abundance of insects in natural habitats. J. Animal Ecology, 38: 497-509.

9. Weigand, J.P. 1980. Ecology of the Hungarian partridge in north central Montana. Wildlife Monographs, 17: $176-177$.

Table 1: Home range and distance covered by Chukar Partridge Alectoris Chukar at Mandal Valley, Garhwal Himalaya, U.K.

\begin{tabular}{|l|l|l|}
\hline Month & Altitude Covered $(\mathbf{m})$ & Distance covered from water source (m) \\
\hline November 2018 & $1720 \pm 8.0$ & $74.12 \pm 4.77$ \\
\hline December & $1712 \pm 11.00$ & $81.31 \pm 5.70$ \\
\hline January 2019 & $1708 \pm 5.00$ & $86.66 \pm 6.72$ \\
\hline
\end{tabular}




\section{International Journal of Current Science Research and Review}

ISSN: 2581-8341

Volume 04 Issue 04 April 2021

DOI: 10.47191/ijcsrr/V4-i4-02, Impact Factor: 5.825

IJCSRR@ 2021

Www.ijcsrr.org

\begin{tabular}{|l|l|l|}
\hline February & $1722 \pm 4.00$ & $82.52 \pm 8.50$ \\
\hline March & $1750 \pm 7.00$ & $61.23 \pm 5.14$ \\
\hline April & $1758 \pm 11.00$ & $50.51 \pm 4.72$ \\
\hline May & $1805 \pm 12.00$ & $41.10 \pm 4.83$ \\
\hline June & $1812 \pm 8.00$ & $39.10 \pm 6.30$ \\
\hline July & $1792 \pm 11.00$ & $63.10 \pm 8.20$ \\
\hline August & $1788 \pm 5.00$ & $99.04 \pm 11.42$ \\
\hline September & $1767 \pm 6.00$ & $83.82 \pm 10.12$ \\
\hline October & $1747 \pm 5.00$ & $71.70 \pm 4.77$ \\
\hline Average & $\mathbf{1 7 5 6 . 7 5} \pm 7.75$ & $\mathbf{6 9 . 5 2} \pm \mathbf{6 . 7 6}$ \\
\hline
\end{tabular}

Table 2: Seasonal Variation in Home range and distance covered by Chukar Partridge Alectoris Chukar at Mandal Valley, Garhwal Himalaya, U.K.

\begin{tabular}{|l|l|l|}
\hline Season & Altitude Covered (m) & $\begin{array}{l}\text { Distance covered from water } \\
\text { source (m) }\end{array}$ \\
\hline Winter (November to January) & $1713.33 \pm 8.0$ & $80.69 \pm 5.73$ \\
\hline Spring (February to April) & $1743.33 \pm 7.33$ & $64.75 \pm 6.12$ \\
\hline $\begin{array}{l}\text { Breeding (Summer) } \\
\begin{array}{l}\text { Monsoon and Post Monsoon } \\
\text { (August to October) }\end{array}\end{array}$ & $1803 \pm 10.33$ & $47.77 \pm 6.44$ \\
\hline
\end{tabular}

Cite this Article: Manish Kukreti, S.P. Uniyal(2021). Home Range and Distance Covered of Chukar Partridge Alectoris Chukar at Mandal Valley, Garhwal Himalaya, India. International Journal of Current Science Research and Review, 4(4), 251-253 